\title{
Undermining oR Promoting Democratic Government? AN ECONOMIC AND EMPIRICAL ANALysis of THE Two Views of Public Sector Collective BARgaining IN AMERICAN LAW
}

\author{
Kenneth G. Dau-Schmidt* \\ Mohammad Khan**
}

I. INTRODUCTION

There are two divergent views on the role of public sector collective bargaining in American law. The first (and generally older) view is that public sector collective bargaining undermines democratic government, allowing organized employees to interfere with the administration of the law for their own personal benefit at the expense of the general population and taxpayer. ${ }^{1}$ Under this view, courts have characterized public employee union membership as "subversive," "inconsistent with . . . discipline," "a direct violation of the constitution," and "detrimental to the general welfare" to rationalize the enforcement of public sector yellow-dog contracts and discriminatory discharges. $^{2}$ On the question of whether legislatures can either allow or prohibit public sector collective bargaining, judges adhering to this negative view of public sector collective bargaining have found that it is an unconstitutional interference with freedom of contract or an unconstitutional delegation of legislative power. ${ }^{3}$

* Willard and Margaret Carr Professor of Labor and Employment Law, Indiana University Maurer School of Law-Bloomington; J.D. (1981) University of Michigan-Ann Arbor; Ph.D. (Economics 1984) University of Michigan-Ann Arbor.

** Employee Services Specialist, P\&O Princess Cruises PLC; J.D. (2012) Indiana University.

1 See generally Joseph E. Slater, Public Workers: Government Employee Unions, the Law, and the State, 1900-1962 (2004); Martin H. Malin, The Paradox of Public Sector Labor Law, 84 IND. L.J. 1369, 1369 (2009).

2 See, e.g., Hutchinson v. Magee, 122 A. 234, 234 (Pa. 1923); Perez v. Bd. of Police Comm'rs, 178 P.2d 537, 545 (Cal. Dist. Ct. App. 1947).

3 See, e.g., McNatt v. Lawther, 223 S.W. 503, 505-06 (Tex. Civ. App. 1920) (government's freedom of contract allows state to prohibit public employee organization), superseded by statute as recognized in City of Round Rock v. Rodriguez, 317 S.W.3d 871 (Tex. App. 2010); City of Springfield v. Clouse, 206 S.W.2d 539, 545 (Mo. 1947) (public sector collective bargaining constitutes an unconstitutional delegation of governmental power), overruled by Independence-Nat'l Educ. Ass'n v. Independence Sch. Dist., 223 S.W.3d 131 (Mo. 
The second view is that public sector collective bargaining is an essential part of our democratic government. Under this view, collective bargaining is a fundamental human right ${ }^{4}$ included in our cherished constitutional rights of free speech and association, ${ }^{5}$ and an essential counterbalance to corporate interests in a pluralistic society. ${ }^{6}$ Supporters would argue that, on the whole, public sector collective bargaining improves democratic outcomes and government administration by giving workers a voice in the outcome. ${ }^{7}$ Public sector unions represent important public policy interests in collective bargaining and legislative lobbying, and act as a check on government monopsony power in employment. $^{8}$

These countervailing views of public sector collective bargaining find representation not only in legal doctrine and opinions, but also in the public policy and economic arguments surrounding this debate. The detractors argue that unions are merely labor cartels that are both inefficient and inequitable, raising wages and benefits at the expense of consumers and taxpayers and imposing

2007). Although American courts now generally accept that it is not unconstitutional for a state or locality to engage in collective bargaining with its employees, it is also generally accepted that there is no constitutional right on the part of those employees to resort to collective bargaining. See, e.g., Smith v. Ark. State Highway Emps., Local 1315, 441 U.S. 463, 464, 466 (1979); Seattle High Sch. Chapter No. 200 of the Am. Fed'n of Teachers v. Sharples, 293 P. 994, 998 (Wash. 1930); Perez, 178 P.2d at 545-46. As a result, in the United States, whether public employees have a right to collectively bargain, and the form of that right, is largely a matter of federal and state legislation. See SLATER, supra note 1, at 82-95.

4 This right is spelled out in Article 23 of the United Nations Universal Declaration of Human Rights, Universal Declaration of Human Rights, G.A. Res. 217 (III) A, U.N. Doc. A/RES/217(III), at 75 (Dec. 8, 1948), and in other international declarations of which the United States is a signatory, such as the 1998 International Labour Organization's Declaration on Fundamental Principles and Rights at Work, ILO Declaration on Fundamental Principles and Rights at Work, International Labor Conference, 86th Sess. (June 18, 1998), available at http://www.ilo.org/declaration/thedeclaration/textdeclaration/lang — en/index .htm.

5 See Catherine Phillips, Note, The Lost Democratic Institution of Petitioning: Public Employee Collective Bargaining as a Constitutional Right, 10 First AmEND. L. Rev. 652, 682-85 (2012).

6 See Clyde W. Summers, Public Employee Bargaining: A Political Perspective, 83 YAle L.J. 1156, 1159 (1974); David Lewin et al., Emp't Policy Research Network \& Labor \& Emp't Relations Ass'n, Getting It Right: Empirical Evidence and Policy Implications from Research on Public-Sector Unionism and Collective Bargaining 28 (2011), available at http://www.employmentpolicy.org/sites/www.employmentpolicy.org /files/EPRN\%20PS\%20draft\%203\%2016\%2011\%20PM\%20FINALtk-ml4\%20edits.pdf;

Martin H. Malin, Does Public Employee Collective Bargaining Distort Democracy? A Perspective from the United States, 34 Comp. Laв. L. \& PoL'y J. 277, 305 (2013); Kazutoshi Koshiro, Does Public Sector Collective Bargaining Distort Democracy in Japan?, 34 CомP. LAB. L. \& Pol'y J. 307, 344 (2013).

7 David Lewin, Public Employment Relations: Confronting the Issues, 12 Indus. Rel. 309, 318-21 (1973). See also Derek C. Bok \& John T. Dunlop, Labor and the American Community 424 (1970). For a discussion of these issues on a comparative basis, see the symposium edition of the Comparative Labor Law \& Policy Journal, Symposium, Public Sector Collective Bargaining and the Distortion of Democracy: Do Public Sector Unions Have "Too Much" Power?, 34 Coмp. LAв. L. \& Pol'y J. 245 (2013).

${ }^{8}$ See Summers, supra note 6, at 1159-61. 
inefficient and inflexible work rules. ${ }^{9}$ Public employee collective bargaining is doubly bad because it often exploits a government monopoly on services and gives public employee interests an elevated status in public policy debates. ${ }^{10}$ These views have found ready representation in the recent debates over legislation to prohibit or restrict public sector collective bargaining in Wisconsin, Ohio, and Indiana, among other states. ${ }^{11}$ On the other hand, the proponents of public sector collective bargaining argue that public employee voice in the provision of government services is valuable and improves the provision of government services and administration of the law. ${ }^{12}$ Public sector unions represent important public policy interests in collective bargaining and legislative lobbying, and act as a check on narrow taxpayer interests and government monopsony power in employment. ${ }^{13}$ Moreover, unions in both the private and the public sectors foster a healthy middle class, promote greater equality in the distribution of income and wealth, and promote the representation of the views of workers in legislative debates. ${ }^{14}$

Many of the broader claims of these two views are subject to empirical analysis. One of the goals of public sector unions is to raise employee wages and benefits over what they would have been in the absence of a union; but are they raised above comparable levels in the private sector at the expense of taxpayers, or do they promote comparable wages that attract good public servants and long-run administrative interests rather than short-term budget cutting interests? Do public sector unions impose work rules and restrictions that interfere with the provision of government services, or do they provide an employee voice that improves government services and the administration of the law? In this article, I will present an outline of the economic arguments both for and against public sector unions, and the empirical evidence supporting or refuting those arguments. My intent is to provide an empirical context for the larger debate regarding public policy with respect to public sector collective bargaining, and the larger constitutional debate over this institution.

9 See Milton Friedman \& Rose Friedman, Free to Choose: A Personal Statement 228-47 (1980); Richard A. Epstein, A Common Law for Labor Relations: A Critique of the New Deal Labor Legislation, 92 Y ALE L.J. 1357, 1365-67, 1382 (1983); Henry C. Simons, Some Reflections on Syndicalism, 52 J. PoL. Econ. 1, 12 (1944).

${ }^{10}$ Harry H. Wellington \& Ralph K. Winter, Jr., The Limits of Collective Bargaining in Public Employment, 78 Yale L.J. 1107, 1108 (1969). See also Jeffrey H. Keefe, A Reconsideration and Empirical Evaluation of Wellington's and Winter's, The Unions and the Cities, 34 Comp. Lab. L. \& Pol'y J. 251 (2013) (examining the empirical basis for Wellington and Winter's arguments).

11 Joseph E. Slater, Am. Const. Soc'y for L. \& Pol'y, The Assault on Public Sector Collective Bargaining: Real Harms and Imaginary Benefits 1-4 (2011), available at http://www.acslaw.org/publications/issue-briefs/the-assault-on-public-sector-collective-bar gaining-real-harms-and-imaginar.

12 BoK \& Dunlop, supra note 7 ("Without union efforts, workers and low-income groups would have little organized political support, and their interests would be more vulnerable to the pressure of other powerful groups.").

13 Summers, supra note 6, at 1159-61.

14 See Boк \& Dunlop, supra note 7; John F. Burton, Jr. \& Charles Krider, The Role and Consequences of Strikes by Public Employees, 79 YALE L.J. 418, 430-32 (1970); Lewin, supra note 7. 


\section{A Primer on the State as an Economically Rational Employer: DifFERENT Is GOOD, AND EXPECTED!}

Regardless of whether public employees are organized or not, economic theory suggests that there should be some predictable differences between the terms and conditions of employment enjoyed by the typical public sector employee and those enjoyed by the typical private sector employee, given the requirements of most government jobs and various characteristics of the government as an employer.

First, there are important demographic differences between public and private employees that have to be taken into account in accurately comparing their relative compensation. As shown in Table 1, on average, public employees have more years of education, more years of experience (age), work fewer hours and are more likely to be female or Black (but not Hispanic) than private sector employees. It is vital to take account of the educational differences between public and private sector workers in comparing their wages and benefits. Many government positions such as teacher, civil engineer, registered nurse, and various administrators, require at least a bachelor's degree, while government-employed professors, lawyers, and doctors must complete advanced or professional degrees in order to do their job competently. ${ }^{15}$ As a result, while only twenty-five to thirty percent of private sector employees have at least a bachelor's degree, over half of public employees have at least a bachelor's degree. ${ }^{16}$ In order to recruit educated people into public sector jobs, these employees have to be compensated for their investment in education; ${ }^{17}$ thus one would expect that, because government workers are, on average, more educated than private sector employees, they should be paid more, on average, than private sector employees. ${ }^{18}$ Similarly, one should also take account of the fact that public employees often work fewer hours and have more years of work experience than private sector employees. ${ }^{19}$ The detractors of teachers have made much of the fact that most work on nine or ten month contracts and, to

15 John Schmitt, The Wage Penalty for State and Local Government Employees, CTR. FOR ECON. \& POL'y Research 4 (2010), available at http://www.cepr.net/documents /publications/wage-penalty-2010-05.pdf.

16 Keith A. Bender \& John S. Heywood, Out of Balance? Comparing Public and Private Sector Compensation Over 20 Years, Ctr. for State \& Local Gov't ExcelLENCE \& NAT'L InSt. ON Ret. SEC. 7 (2010), available at http://slge.org/wp-content /uploads/2011/12/Out-of-Balance_FINAL-REPORT_10-183.pdf (noting that only $22.6 \%$ of private sector workers have at least a bachelor's degree, while $47.9 \%$ of public sector workers have at least a bachelor's degree).

17 Craig Olson, The Battle Over Public Sector Collective Bargaining in Wisconsin and Elsewhere, Emp't. Policy Research Network (Mar. 1, 2011), http://www.employmentpolicy .org/topic/402/op-ed/battle-over-public-sector-collective-bargaining-wisconsin-and-else where.

18 LEwIN ET AL., supra note 6, at 4. Studies that fail to take account of this fact fall subject to what is known as "Simpson's Paradox": that although average compensation of all public sector workers is higher than the average compensation of all private sector workers, the public sector workers might be paid less at each level of educational achievement. See Bender \& Heywood, supra note 16, at 5-6.

19 Jeffrey Keefe, Econ. Pol'y Inst., Briefing Paper \#276, Debunking the Myth of the Overcompensated Public Employee 10 (2010), available at http://www.epi.org/files /page/-/pdf/bp276.pdf. 
give them their due, one would rationally expect that these teachers would be paid less than comparable private sector employees who worked year round. ${ }^{20}$ The fact that public employees currently are, on average, older and have more years of work experience than private sector employees is probably due to increased growth in state jobs during the 1950s and 60s. ${ }^{21}$ One would expect that employees with more years of job experience would be compensated more, and this fact should be taken into account in comparing private and public compensation. Finally, although theoretically there should be no difference in compensation based on gender, race, or ethnicity, historically women and minority groups have done better in public employment. ${ }^{22}$ It is at least interesting to control for systematic differences between private and public compensation based on race, ethnicity, and gender, although in this case lower wages in the private sector may be an indication of discrimination.

TABle 1: Characteristics of Private, State, and Local Employees $(2008 \text { AND 2009) })^{23}$

\begin{tabular}{|l|r|r|r|c|}
\hline & Private & State & Local & State \& Local \\
\hline Demographics & 103.2 & 6.0 & 10.7 & 16.7 \\
\hline Number (Millions) & 2197 & - & - & 2156 \\
\hline Annual Hours Worked ${ }^{24}$ & 40 & 43 & 44 & 44 \\
\hline Median Age (Years) & 8.5 & 1.9 & 2.8 & 2.5 \\
\hline Education (\%) & 31.1 & 17.9 & 21.1 & 19.9 \\
\hline Less Than High School & 30.6 & 27.1 & 26.5 & 26.7 \\
\hline High School & 20.9 & 27.5 & 27.4 & 27.4 \\
\hline Some College & 8.9 & 25.6 & 22.3 & 23.5 \\
\hline College Degree & 46.2 & 59.1 & 60.8 & 60.2 \\
\hline Advanced Degree & 9.6 & 13.4 & 11.5 & 12.2 (est) \\
\hline Gender, Race, Ethnicity (\%) & 17.1 & 8.3 & 10.8 & 9.8 (est) \\
\hline Women $^{25}$ & Black \\
\hline Hispanic & 26 &
\end{tabular}

20 Joel, Critics Claim Teaching Is a Part-Time Job at Full Pay Wages, Teaching CommuNITY, http://teaching.monster.com/careers/articles/8021-critics-claim-teaching-is-a-part-time -job-at-full-pay-wages (last visited Mar. 6, 2014).

21 Kenneth G. Dau-Schmidt et al., Labor Law in the Contemporary Workplace 83 (2009).

22 Joseph G. Altonji \& Robert Blank, Race and Gender in the Labor Market, in HaNDBooK of LABOr Economics (O. Ashenfelter and D. Card, eds. 1999); Martin Asher and Joel Popkin, The Effect of Gender and Race Differentials on Public-Private Wage Comparisons: A Study of Postal Workers, 38 Indus. \& Lab. Rel. Rev. 16 (1984-1985).

${ }^{23}$ Schmitt, supra note 15, at 3 tbl.1 (analysis of CEPR extract (version 1.5) of 2009 CPS ORG).

${ }^{24}$ KeEFE, supra note 19, at 10 tbl.5 (analysis of 2009 CPS data for private and public employees).

25 Bender \& Heywood, supra note 16, at 7 tbl.1 (2008 CPS data).

26 Id. 
Second, the state is a relatively large employer, and large employers are good at bearing risk because they have a large number of employees over which risk can be pooled; they also enjoy economies of scale in the coverage of risk. $^{27}$ As a result, large employers can more efficiently offer benefits such as health insurance and pensions that insulate employees from risk, and it is predictable that benefits would constitute a larger percent of the employees' compensation package for large employers like the state. ${ }^{28}$ Because of its relative insulation from market fluctuations and its high degree of credit-worthiness, the state is a particularly good risk-bearer, even among large employers. Thus it is predictable that, even in comparison with other large employers, the state would offer to bear or insure employee risk through the provision of various benefits in exchange for relatively lower wages. Accordingly, one would expect that the typical public employee compensation package would include a higher percentage of compensation in benefits such as healthcare and pensions, and a lower percent in upfront wages, in comparison with the compensation packages of typical private employees. ${ }^{29}$

Third, the demand for government services is more predictable than the demand for most private businesses and thus, as an employer, the state probably does not place as high a premium on having flexibility to lay off employees as do private businesses. A rational state would want to maintain public employment in hard economic times as a counter-cyclical check against recession. ${ }^{30}$ Indeed, the demand for many government services increases in hard economic times, ${ }^{31}$ so a state might actually want to employ more workers rather than fewer when the economy contracts. As a result, one would expect that, rationally, the state would want to offer job stability to employees in exchange for lower wages, and one would expect that state employees would enjoy greater job security than comparable private sector employees. ${ }^{32}$ Indeed, historically, the necessity of protecting valuable state employees and their positions from political cronyism or patronage has required strict protection under civil service laws. ${ }^{33}$ The rational intertemporal bargain between the state and its employees would be that state employment and wages would not increase as fast as those of private employees in good economic times, but they would also be maintained or at least not decrease as fast as those of private sector employ-

27 See William E. Even \& David A. Macpherson, Employer Size and Compensation: The Role of Worker Characteristics, 26 ApPLIED ECON. 897, 897 (1994).

28 See Lewin et AL., supra note 6, at 7; Bender \& Heywood, supra note 16, at 15. Benefits are also generally higher for more educated workers. Since public workers are generally more educated than private sector workers, this would also argue in favor of higher benefits for state employees. Id.

29 See Lewin ET AL., supra note 6, at 4.

30 See Matissa Hollister, Employment Stability in the U.S. Labor Market: Rhetoric Versus Reality, 37 Ann. Rev. Soc. 305, 313 (2011).

31 How Have State Governments Fared During the Recent Recession?, Fed. Res. BAnK of S.F. (Oct. 2010), http://www.frbsf.org/education/publications/doctor-econ/2010/october/re cession-state-government.

32 Lewin ET AL., supra note 6, at 29.

${ }^{33}$ For a discussion on state employees and patronage, see generally Bryan A. Schneider, Note, Do Not Go Gentle into That Good Night: The Unquiet Death of Political Patronage, 1992 Wis. L. REv. 511. 
ees in bad economic times. ${ }^{34}$ The predictability of government work might also allow the government to offer expected hours of work for public employees that are more predictable than those for comparable employees in the private sector, once again with a commensurate deduction in wages.

Thus, even in an atomistic competitive labor market, without unions or political advocacy, one would expect that public employee compensation, including the value of both wages and benefits, would on average be higher than that for all private employees (because of the greater average educational requirements of public employment jobs), but that the compensation package for public employees would include relatively lower wages and higher benefits, including job security, than that for private sector employees. Simple analyses which assume that any difference between the compensation packages of public and private employees in either amount or wage and benefit mix is a sign of government waste and inefficiency or political favoritism are simply wrong. ${ }^{35}$ Because of the differences in the optimal compensation package for public and private employees, the government will tend to attract employees who are particularly risk-averse as well as those who particularly enjoy the type of work the government has to offer, and thus for whom the government's proffered trade-off of benefits and wages is a particularly good deal. Therefore, people who are relatively risk-averse and place a lower value on income will tend to go into government work while people who are relatively risk-seeking and put a high value on income will tend to go into the private sector. ${ }^{36}$ However, taking account of these differences in preferences, in order to attract people of comparable skills to forgo private sector opportunities and enter and remain in government employment, the government will have to offer public employees a wage and benefits package that, over the course of their career, is equal in expected value to what they would have received in a career in the private sector. If the government offers a less attractive package, it will attract less talented workers and lose its more talented workers to the private sector.

\section{Public Employees and the Two Views of Unions And Collective Bargaining in Economics}

\section{A. Public Employee Unions as Labor Cartels and Special Interest Groups}

The simple economic analysis of unions, in either the private or public sector, is that they are labor cartels that impose on employers wage demands and other terms and conditions of employment that are both inefficient and

\footnotetext{
${ }^{34}$ See Don Bellante \& Albert N. Link, Are Public Sector Workers More Risk Averse Than Private Sector Workers?, 34 Indus. \& Lab. Rel. Rev. 408, 408-09 (1981).

35 For examples of poor analyses of public employee wages and benefits that are simply wrong, see Dennis Cauchon, Benefits Widen Public, Private Workers' Pay Gap, USA ToDAY, http://usatoday30.usatoday.com/money/workplace/2009-04-09-compensation_N .htm (last updated Apr. 10, 2009, 2:23 AM) (failure to account for educational differences); Editorial Board, Squealing About the Income Gap, Sun J. (Oct. 1, 2009), http://www.sun journal.com/node/287310 (failure to account for educational differences).

36 See Bellante \& Link, supra note 34 , at 411-12.
} 
inequitable. ${ }^{37}$ Under the simple neo-classical analysis, such labor cartels cause inefficient production and consumption, unemployment, and a displacement of workers from organized work to unorganized work, depressing wages there. ${ }^{38}$ They are also inequitable because employee wage increases come at the expense of consumers or taxpayers who are not necessarily any wealthier than public employees. ${ }^{39}$

This simple analysis is presented in Figure 1. Figure 1(a) represents the organized labor market where the vertical axis measures the employees' wages, the horizontal axis measures the number of full-time employees employed, the solid downward-sloping curve labeled D represents the employers' labor demand curve, and the solid upward-sloping curve labeled S represents the employees' labor supply curve. Figure 1(b) represents the unorganized labor market, with analogous demand and supply curves. Prior to the entry of the union, both the organized and the unorganized markets are in equilibrium with a competitive wage $\left(\mathrm{W}_{\mathrm{c}}\right)$, a competitive level of employment $\left(\mathrm{N}_{\mathrm{c}}\right)$, and supply equals demand $(\mathrm{S}=\mathrm{D}){ }^{40}$ Under the traditional analysis, when the union organizes a sufficient number of employees in the relevant product market, it imposes a monopoly wage on the employers in the organized market $\left(\mathrm{W}_{\mathrm{u}}\right)$ which the employers must pay to employ labor. Barriers to entry prevent the organized employers from replacing the employees, ${ }^{41}$ and the employer responds by moving up his demand curve, reducing employment from $\mathrm{N}_{\mathrm{c}}$ to $\mathrm{N}_{\mathrm{u}}$.

The traditional analysis depicted in Figure 1 outlines inefficiencies and inequity that the detractors have generally ascribed to collective bargaining. In response to the union wage, the employer accomplishes the decrease in employment by reducing production and substituting capital for labor in the production process, resulting in production inefficiency. ${ }^{42}$ The higher union wage also results in unemployment because more workers $\left(\mathrm{N}_{\mathrm{s}}\right)$ would like to work at the union wage than the employers are willing to employ $\left(\mathrm{N}_{\mathrm{u}}\right)$. As shown in Figure 1, some of these workers $\left(\mathrm{N}_{\mathrm{c}}-\mathrm{N}_{\mathrm{u}}\right)$ seek employment in the unorganized labor market shown in Figure 1(b), pushing out the labor supply

37 See Friedman \& Friedman, supra note 9, at 247; Epstein, supra note 9, at 1365-66; Simons, supra note 9, at 12.

38 Kenneth G. Dau-Schmidt, A Bargaining Analysis of American Labor Law and the Search for Bargaining Equity and Industrial Peace, 91 Мich. L. Rev. 419, 453-54 (1992); HAROLD W. Davey et al., Contemporary Collective Bargaining 306, 337 (4th ed. 1982).

39 See Kenneth G. Dau-Schmidt \& Arthur R. Traynor, Regulating Unions and Collective Bargaining, in LABor AND EMPloyment Law AND Economics 96, 105 (Kenneth G. DauSchmidt et al. eds., 2009); Dau-Schmidt, supra note 38, at 458.

40 For the standard presentation of this analysis, see RonAld G. Ehrenberg \& Robert S. Smith, Modern Labor Economics: Theory and Public Policy 450-52 (11th ed. 2012).

${ }^{41}$ Critics argue that, in the public sector, there is often a government-maintained monopoly on the provision of government services. This monopoly protects union monopoly wages from being bid down by competition. James Sherk, The Heritage Found., BackGrounder No. 2275, What Unions Do: How Labor Unions AfFect Jobs and the EConому 1, 3 (2009), available at http://www.heritage.org/research/reports/2009/05/what -unions-do-how-labor-unions-affect-jobs-and-the-economy.

42 See Ehrenberg \& Smith, supra note 40, at 450, 474-75, 511-12; Barry T. Hirsch \& John T. Addison, The Economic Analysis of Unions: New Approaches and Evidence 21-22, 181 (1986). 
curve in that market from $\mathrm{S}$ to $\mathrm{S}^{\prime}$ and depressing wages from $\mathrm{W}_{\mathrm{c}}$ to $\mathrm{W}^{\prime}{ }_{\mathrm{c}}{ }^{43}$ Moreover, the decrease in production by the organized firms and the increase in the organized employees' wage results in an increase in the product price to the consumer or taxpayer. This leads to "consumption inefficiency" because the consumers or taxpayers will now buy too little of the good relative to other goods. ${ }^{44}$ Using this model, it is commonly argued that the increase in union wages is inequitable since it comes at the expense of consumers and non-union workers who are probably not significantly richer than the union employees. ${ }^{45}$ Finally, critics argue that public sector unions use political pressure to maintain the product market monopoly and pressure public employers to accede to union demands. Drawing on public choice theory, these critics argue that public employees are a narrow interest group that can gain personal benefits at the expense of the larger electorate. ${ }^{46}$

\section{Figure 1: The Simple Neoclassical Model of Unions and Collective Bargaining}
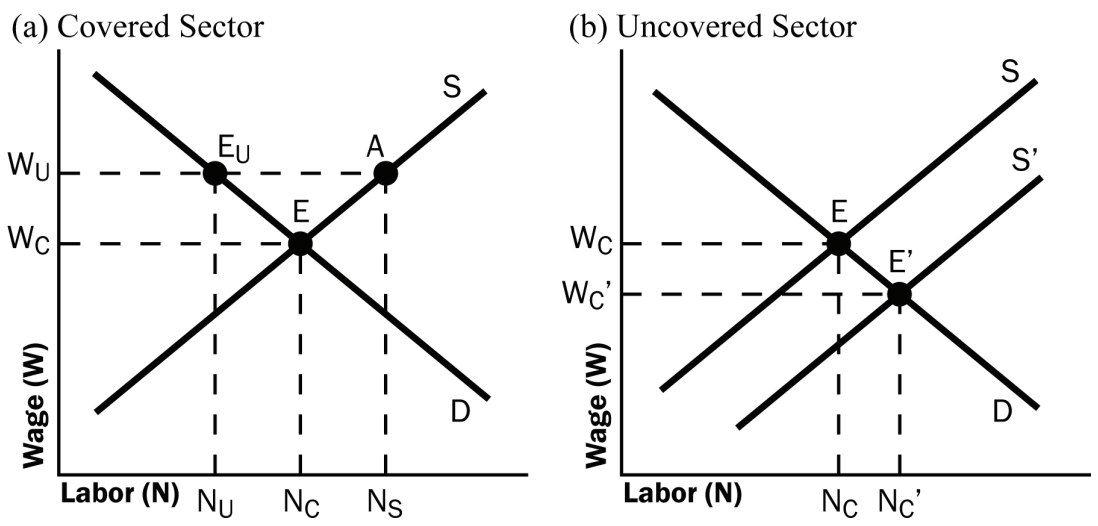

Based on the above analysis, conservatives argue that public employee unions impose wages and benefits that are higher than those enjoyed by comparable private sector employees who are not organized. ${ }^{47}$ These higher wages and benefits raise the cost of government services and cause inefficient production and consumption. ${ }^{48}$ Higher wages and benefits are also inequitable because they come at the expense of taxpayers who may not be as wealthy as

43 This movement of employees from an organized to an unorganized job market is generally known as the "displacement effect." Dau-Schmidt, supra note 38; DAVEY ET AL., supra note 38, at 306; Ehrenberg \& SMith, supra note 40 at 474-75.

44 See Ehrenberg \& Smith, supra note 40, at 453, 474. See also Hirsch \& Addison, supra note 42 , at $22,181$.

45 Dau-Schmidt, supra note 38, at 458.

46 See Nick Adnett \& Peter Davies, Markets For Schooling: An Economic Analysis 7-9 (2002) (explaining public choice theory in the context of public schools); DenNis C. Mueller, Public Choice III 473 (2003).

47 See James Sherk, The Heritage Found., Backgrounder No. 2522, Time to Restore Voter Control: End the Government-Union Monopoly 4 (2011), available at http:// thf_media.s3.amazonaws.com/2011/pdf/bg2522.pdf.

${ }_{48} I d$. at 7. 
the public employees. ${ }^{49}$ Moreover, public employee collective bargaining undermines our democratic government by establishing a special interest group with an interest in gaining wages and benefits at the expense of ordinary taxpayers. ${ }^{50}$ These special interest groups undermine the working of our democratic government because they have a concentrated interest in rent-seeking at the expense of the larger electorate's interest in the efficient provision of government services. ${ }^{51}$ As a solution to these problems, conservatives have argued that we should prohibit collective bargaining in the public sector (and in the private sector too). ${ }^{52}$

Even before we get to the empirical question of whether public sector employees (and, in particular, organized public employees) are overpaid, there are some logical objections that can be raised to the conservative account. It seems a gross exaggeration to say that public sector unions in the United States establish a labor cartel that dictates wage and benefit increases. Even before the recent round of state statutes limiting or doing away with collective bargaining rights, only thirty-four states had comprehensive public sector collective bargaining laws, and only eight had statutes allowing any public employees even a limited right to strike. ${ }^{53}$ There is no right to strike among federal employees, ${ }^{54}$ and strikes in violation of this stricture have met with wholesale termination of the striking federal employees. ${ }^{55}$ For the vast majority of American public sector employees, if there is any right to collectively bargain, it is more a right to consultation with a possible resort to neutral fact-finding or arbitration on disputed topics. The primary benefits to American public employees from collective bargaining are their association with other employees with similar interests, a First Amendment right, and the opportunity to have signed contracts on their terms and conditions of employment that are enforceable for a period of time, generally two to four years-most often two.

Secondly, private outsourcing has proven in many cases to be a poor alternative to the provision of public goods and services with public employees. There have been some notable failures in public outsourcing of late. In Pennsylvania, the owners of private youth detention facilities bribed judges to fill their cells and work programs, resulting in the wrongful incarceration of hundreds of young people and the death of at least one young man, Edward Kenzakowski. ${ }^{56}$ The obvious lesson from this case seems to be that it is very

49 See id. at $4,7$.

50 Id. at 7.

51 Id. at 3.

52 See generally Judith Davidoff, Walker's Plan to End Bargaining Has Deep Roots in GOP, CAP Times (Feb. 23, 2011, 10:00 AM), http://host.madison.com/ct/news/local/govt -and-politics/article_b4b509b4-3ed0-11e0-b97e-001cc4c03286.html.

53 DAU-SCHMidT ET AL., supra note 21, at 84-85.

545 U.S.C. $\$ 7116(\mathrm{~b})(7)$ (2012). See Mark D. Roth \& Jamison F. Grella, First Line Defenders as Second Class Citizens: Collective Bargaining Rights for TSA Employees and National Security Make Good Bedfellows, 1 NAT'L SECURITY L. BRIEF 117, 122 (2010); Joseph A. McCartin, Re-Framing US Labour's Crisis: Reconsidering Structure, Strategy, and Vision, Labour/Le Travail, Spring 2007, at 133, 138.

55 Bernard D. Meltzer \& Cass R. Sunstein, Public Employee Strikes, Executive Discretion, and the Air Traffic Controllers, 50 U. CHI. L. Rev. 731, 731 (1983).

56 'Kids for Cash' Judge Gets 28 Years in Pennsylvania Bribery Case, Guardian, Aug. 11, 2011, at 20, available at http://www.theguardian.com/world/2011/aug/11/kids-for-cash 
dangerous to align the coercive power of the state with the private profit motive. Private subcontracting was also extensively used in the wars in Iraq and Afghanistan because the wars had exhausted available government personnel. ${ }^{57}$ This outsourcing resulted in the deaths of American service people, ${ }^{58}$ the failure of training programs that were at the core of the mission, ${ }^{59}$ and billions of dollars in waste, graft, and fraud. ${ }^{60}$ The empirical evidence suggests that early efforts at privatization in the 1970s and 80 s yielded efficiencies, but at least since the 1990s there has been no systematic relationship between privatization and government savings. ${ }^{61}$ It seems that private companies and entrepreneurs are better than public sector employees at rent-seeking, influencing legislators, and "undermining" democratic processes. This is probably predictable within the context of the neoclassical model since the rents are more concentrated and less transparent in the profits of a private company than when a public union lobbies for program improvements, better wages, and better working conditions in public collective bargaining agreements. This greater concentration of rents in private contracting is also arguably less equitable than when any benefits of lobbying are dispersed among many public employees. Blind bidding of construction projects to private contractors has proven useful and efficient, so private outsourcing can sometimes be useful, but it is a mistake to assume that just because work is being done by a private contractor that public services are being adequately and efficiently delivered. For the provision of public goods that have to be paid out of the public purse, public employees usually do a better job with less waste, graft, and fraud than what is lost as a result of outsourcing to private companies. ${ }^{62}$

-judge-pennsylvania; Michael Rubinkam, Pa. Judge Guilty of Racketeering in Kickback Case, Huffington Post (Feb. 19, 2011, 3:04 AM), http://www.huffingtonpost.com/huff -wires/20110219/us-courthouse-kickbacks/.

57 Jeremy Scahill, The Mercenary Revolution: Flush with Profits from the Iraq War, Military Contractors See a World of Business Opportunities, InDyPENDENT (Aug. 10, 2007), http://www.indypendent.org/2007/08/10/mercenary-revolution-flush-profits-iraq-war-mili

tary-contractors-see-world-business-opportunities; Daniel Schulman, Afghan Police Training: “An Unbelievably Incompetent Story”, Mother Jones (Apr. 16, 2010, 2:00 AM), http ://motherjones.com/mojo/2010/04/afghan-police-training-unbelievably-incompetent-story.

58 See U.S. Electrocution Deaths in Iraq Probed, CBS News (Feb. 11, 2009, 2:42 PM), http://www.cbsnews.com/stories/2008/07/01/iraq/main4223114.shtml.

59 Schulman, supra note 57.

60 Richard Lardner, Up to \$60B in War Funds Said Wasted, Yahoo News India (Aug. 31, 2011), http://in.news.yahoo.com/ap-exclusive-60b-war-funds-said-wasted-210817969.html.

${ }^{61}$ Keefe, supra note 10, at 254. See George A. Boyne, Public Choice Theory and Local Government: A Comparative Analysis of the UK and the USA 150, 165-67 (1998); Graeme A. Hodge, Privatization: An International Review of Performance $155-56$ (2000).

62 See Hasan Saleem, How Outsourcing Affects the U.S. Economy, Directory J. (Apr. 16, 2013), http://www.dirjournal.com/business-journal/how-outsourcing-affects-the-us-econ omy/. See also Outsourcing Statistics in Perspective, CTr. FOR AM. Progress (Mar. 16, 2004), http://www.americanprogress.org/issues/tax-reform/news/2004/03/16/639/outsourc ing-statistics-in-perspective; Job Outsourcing Statistics, Statistic Brain, http://www.statis ticbrain.com/outsourcing-statistics-by-country/ (last visited Mar. 6, 2014). 


\section{B. Employee Voice at Work and in Our Democracy}

The neoclassical analysis of unions as labor cartels is logically incomplete and far too simple for such a complex phenomenon. The basic neoclassical analysis ignores the benefits of efficient negotiations between the union and the employer and the possibility of employer monopsony power. It would be irrational for the union to dictate wages while the employer sets employment; instead, the parties should rationally bargain over both wages and employment to reach Pareto optimal agreements. ${ }^{63}$ In the case of employer monopsony power, collective bargaining can move the parties to a more efficient level of wages and employment. ${ }^{64}$ Moreover, it has been persuasively argued that collective bargaining can raise efficiency by providing a role for employee voice in the production process and the negotiation and enforcement of contract terms. ${ }^{65}$ Employees, especially skilled professional employees like many public employees, can provide useful input into the production process and act as useful monitors of management performance in the workplace. ${ }^{66}$ Unions can also be useful in negotiating efficient contract terms over public goods in the workplace and enforcing efficient deals between employees and employers over time. ${ }^{67}$ Finally, public employee unions can be useful in the political process, representing the benefits of the programs in which they work and the underrepresented perspective of working Americans in general. As a result, far from simply being an exercise in rent-seeking, the participation of public sector unions in the political process makes an important contribution to pluralism in our democracy. ${ }^{68}$

\section{Pareto Optimal Bargaining}

Unless one wants to assume that unions are entirely indifferent to the unemployment of their members, the simple depiction of collective bargaining in the neoclassical model in which the union sets the wage and the employer responds by setting employment will not be Pareto optimal for the parties. Although the employer's labor demand curve gives the profit-maximizing response to a market increase in wages, if the wage increase results from the formation of a union that can bargain over both wages and employment, it can be shown that the employer and union can negotiate a wage and employment

63 An outcome is Pareto optimal, if none of the concerned parties can be made better off without making one worse off. Pareto optimality exists in a deal between two parties when they have exhausted all efficient exchanges between them. GEORge J. BorJas, LABOr ECONOMICS 435 (6th ed. 2013).

${ }_{64}$ See infra text accompanying note 78 .

65 Richard B. Freeman \& James L. Medoff, What Do Unions Do? 8-9 (1984).

66 See Matthew T. Bodie, Workers, Information, and Corporate Combinations: The Case for Nonbinding Employee Referenda in Transformative Transactions, 85 WASH. U. L. Rev. 871, 899 (2007); Kenneth G. Dau-Schmidt, Promoting Employee Voice in the American Economy: A Call for Comprehensive Reform, 94 MarQ. L. Rev. 765, 802 (2011); DauSchmidt, supra note 38, at 431; Peter Kuhn, Union Productivity Effects and Economic Efficiency, 6 J. LAB. Res. 229, 230 (1985).

${ }^{67}$ Dau-Schmidt, supra note 38, at 431-32; Kuhn, supra note 66, at 230.

68 See Jacob S. Hacker \& Paul Pierson, The Wisconsin Union Fight Isn't About Benefits. It's About Labor's Influence, WASH. Post, Mar. 6, 2011 (Sunday Outlook), available at http:// www.washingtonpost.com/wp-dyn/content/article/2011/03/04/AR2011030406264.html. 
agreement that specifies a higher level of employment and a lower wage that both the employer and union will prefer to the employer's labor demand response. ${ }^{69}$ Certainly, if one were to assume that the parties bargain to maximize the monetary value of rents and productivity increases due to unionization, one can demonstrate that the parties will seek to minimize the impact of the union on product price and firm employment levels. ${ }^{70}$

To demonstrate this superior "bargaining solution," I have redrawn in Figure 2 "the labor demand analysis" of Figure 1(a) and included some graphical representations concerning the employer's profitmaking opportunities and the union's preferences among different levels of wages and employment. ${ }^{71} \mathrm{Just}$ like in Figure 1(a), the vertical axis quantifies the employees' wage, the horizontal axis quantifies the number of full-time employees employed, the solid downward-descending curve labeled D signifies the employer's labor demand curve and the solid upward sloping curve labeled S signifies the employees' labor supply curve. However, I have also included employer isoprofit curves $\mathrm{P}_{0}, \mathrm{P}_{1}$, and $\mathrm{P}_{2}$, which descend on each side of the labor demand curve. Each isoprofit curve graphs wage and employment mixes that yield equivalent levels of profit and they descend on either side of the firm's demand curve because at less optimal levels of employment the employer requires a lower wage to achieve the same profits. Isoprofit curves that are lower in the graph $\left(\mathrm{P}_{2}\right)$ specify a higher level of profits than those that are higher in the graph $\left(\mathrm{P}_{0}\right)$ because they signify lower wage levels for any given level of production. ${ }^{72}$ Additionally seen in Figure 2 are the union's indifference curves, $\mathrm{U}_{0}$ and $\mathrm{U}_{1}$. Each indifference curve graphs wage and employment mixes that yield equal utility to the union as a collective entity in choosing what level of wages and employment to accept. Indifference curves that are further from the origin $\left(U_{1}\right)$ yield higher utility than those that are closer to the origin $\left(\mathrm{U}_{0}\right)$ because they signify higher wage levels for any given level of employment. ${ }^{73}$

The superiority of the parties' bargaining response to those set forth in the neoclassical model can now be demonstrated. ${ }^{74}$ When the workers organize and demand union wages, $\mathrm{W}_{\mathrm{u}}$, an employer's labor demand response is to move to point $A$ and reduce the number of employees working to $N_{u}$. However, the firm can achieve the same level of profits it would obtain at $\mathrm{W}_{\mathrm{u}}$ and $\mathrm{N}_{\mathrm{u}}$, while still increasing the union's utility, by moving to the right along the firm's isoprofit curve $\mathrm{P}_{0}$ and agreeing to any point on $\mathrm{P}_{0}$ between $\mathrm{A}$ and $\mathrm{C}^{\prime}$. Similarly, the union can achieve the same level of utility that it would achieve at $\mathrm{W}_{\mathrm{u}}$ and $\mathrm{N}_{\mathrm{u}}$, while still allowing the firm to achieve a higher level of profits, by moving to the right from A along the union's indifference curve $\mathrm{U}_{0}$ and agreeing to any point on $\mathrm{U}_{0}$ between $\mathrm{A}$ and $\mathrm{C}^{\prime \prime}$. The tangencies between the firm's isoprofit

69 See Dau-Schmidt, supra note 38, at 435.

70 Id. at $435-36$.

71 Id. at 436.

72 Id. at 436-37 ("For any given wage, profit is maximized on the labor demand curve; however, identical profits can be made with either more or less labor at a lower wage rate. Accordingly, the isoprofit curves slope down on either side of the labor demand curve.").

73 Id. at 437-38 ("Assuming that the union's utility is an increasing function of both wages and employment, the union's indifference curves will be concave toward the origin as depicted in Figure 2.").

74 Id. at 438. 
curves and the union's indifference curves describe the set of Pareto optimal bargains between the employer and the union and are referred to as the parties' "contract curve," labeled C. ${ }^{75}$ The shape and slope of the contract curve depend on the technology of the firm and the preferences of the union. However, assuming that the union values both high wages and the employment of its members, the contract curve will lie to the right of the employer's labor demand curve. ${ }^{76}$ Assuming that the parties bargain in a Coasean fashion to exhaust all benefits of trade, one would logically conclude that they will agree to a wage and employment bargain that is to the right of the demand curve on the portion of the contract curve between $C^{\prime}$ and $C^{\prime \prime}{ }^{77}$ Precisely where on the contract curve the parties will agree to operate is an indeterminate bargaining problem. However, under any of the possible solutions between $C^{\prime}$ and $C^{\prime \prime}$, the employer will employ more labor after the union wage increase than the amount specified by the employer's labor demand curve. ${ }^{78}$

Figure 2: The Efficient Contract Curve

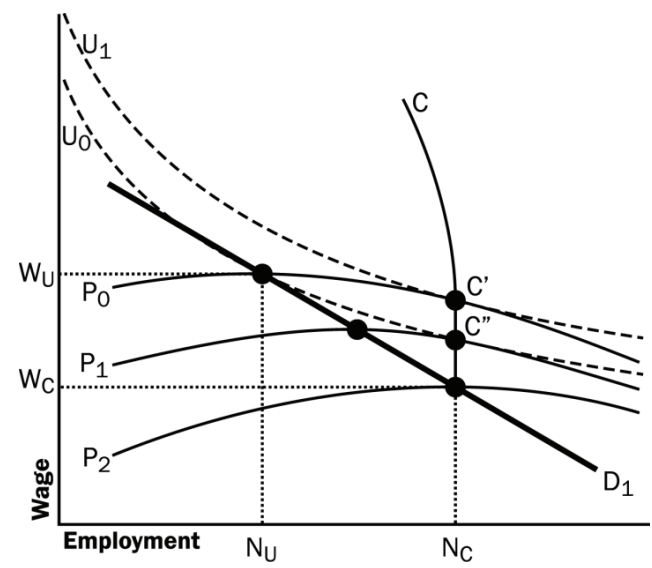

\section{Employer Monopsony Power}

Moreover, if the employer enjoys monopsony power in the labor market, it can be shown that the formation of a union can actually move the employer to a more efficient wage and level of employment through collective bargaining. ${ }^{79}$ An employer exercises monopsony power when it employs such a significant share of the labor in the relevant labor market that it realizes its wage policies affect the market wage. ${ }^{80}$ When an employer monopsony exists, the employer no longer has to accept the market wage as given, but instead realizes that it can drive down the market wage by employing fewer employees. As characterized

75 Id. See also Hirsch \& AdDison, supra note 42, at 16.

76 Dau-Schmidt, supra note 38, at 439.

77 Id. To assume that two parties bargain in a Coasean fashion is to assume they bargain cooperatively to maximize the net benefits of trade. See R. H. Coase, The Problem of Social Cost, 3 J.L. \& ECON. 1, 42-44 (1960).

78 Dau-Schmidt, supra note 38, at 439.

79 Id. at $455-56$.

80 See Davey Et AL., supra note 38, at 307-08. 
in Figure 3, which shows the relevant labor supply curve (S), the employer's labor demand curve (D) and marginal cost of labor curve (MCL), the monopsonistic employer maximizes profits by employing fewer employees $\left(\mathrm{L}_{\mathrm{m}}\right)$ and driving the wage down from $\mathrm{W}_{\mathrm{c}}$ to $\mathrm{W}_{\mathrm{m}} \cdot{ }^{81}$ The actions of the monopsonist in decreasing employment and wages results in production inefficiency because the monopsonist employs less than the efficient amount of labor in the production process. A union can solve this problem because, by fixing the wage for labor at a given rate, it prevents the monopsonist from driving down wages by employing fewer workers. Because the monopsonist can no longer drive down the wage by cutting employment, the monopsonist no longer has incentive to employ fewer than the efficient number of employees. ${ }^{82}$ The problem of the negotiation of a wage between a monopsony employer and a monopoly union represents an indeterminate bargaining problem, but if one assumes the employer and the union seek to maximize the monetary value of the rents from their endeavors, they will bargain to the competitive wage $\left(\mathrm{W}_{\mathrm{c}}\right)$ and the competitive level of employment $\left(\mathrm{L}_{\mathrm{c}}\right){ }^{83}$ Thus, when facing employer monopsony power, monopoly unions can increase employment and economic efficiency.

\section{Figure 3: A Monopsonistic Labor Market}

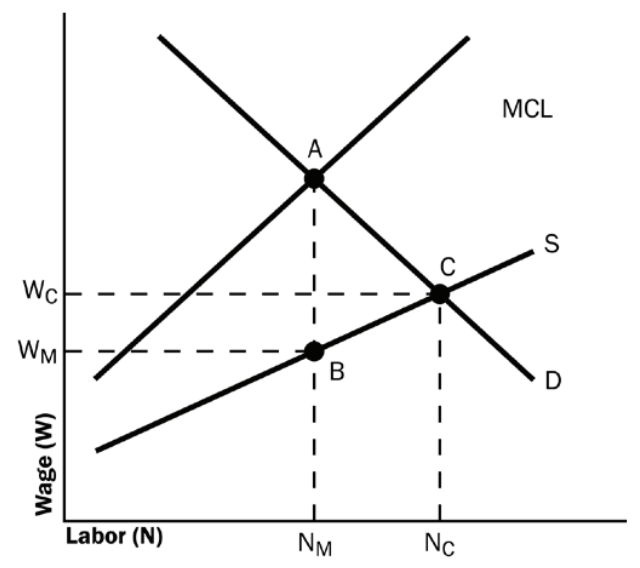

81 The marginal cost of labor curve for the monopsony (MCL) lies above the labor supply curve. This is because the monopsonist realizes that purchasing additional labor drives up the wage; the marginal cost of additional labor for the monopsonist equals the increased wage it must pay for the additional labor plus the increase in wages that must be paid to each previously purchased unit of labor. Because the height of the labor supply curve is equal to the wage at every level of employment, the marginal cost of the labor curve must lie above this curve. As depicted in Figure [2], the monopson[ist] maximizes profits by employing labor until the point where the marginal cost of labor equals the marginal benefit of labor as represented by the labor demand curve ... ( $(\mathrm{Nm})$.

Dau-Schmidt, supra note 38, at 455-56 n.114.

82 "When confronted by a union, the monopsonist faces a marginal cost of labor curve that is horizontal at the union wage from the origin until the labor supply curve and then rises above the labor supply curve." Id. at $456 \mathrm{n} .115$.

83 See Davey Et AL., supra note 38, at 308-09; see also W. Kip Viscusi, Union, Labor Market Structure, and the Welfare Implications of the Quality of Work, 1 J. LAB. REs. 175, 179-84, 190 (1980). 


\section{Productivity-Enhancing Effects of Unions}

There are also a variety of economic theories under which unions and collective bargaining can increase the productivity of the employees and the efficiency of their terms and conditions of employment. ${ }^{84}$ First, unions can allow employees to make useful contributions in organizing the production process and monitoring the work of administrators and managers. ${ }^{85}$ Employees have an obvious interest in the success of their employer and the productivity of their work. Working for a failing employer in a dead-end, unproductive job is neither fulfilling nor secure. Moreover, employees, and in particular skilled or educated employees, have important knowledge of the production process that is useful in planning production to make the enterprise more successful, including experience with the performance of their managers and administrators. ${ }^{86}$ For example, it would be silly to try to plan school policies or curricula without consulting with the teachers who have been trained to educate children and who are actually involved in the day-to-day running of the schools. Discussions with collective representatives in a union setting are more likely to be productive than individual discussions because employees will have less fear of retaliation for reporting administrative failures. ${ }^{87}$

Second, unions help to promote the negotiation of efficient contract terms. Many terms and conditions of employment are public goods in that they are the same for all employees, and an individual employee cannot negotiate improvements without benefiting others. Examples include: common hours of work, the common method of evaluation, and the general form of medical or pension benefits. ${ }^{88}$ Because improvements in these public goods are not exclusive, individual employees have too little incentive to negotiate for them, resulting in a contract for employment that includes too little of these benefits. Unions help to solve this problem by giving the workers a collective voice through which they can more accurately represent their preferences on such matters. ${ }^{89}$ There are also terms and conditions of employment for which there are important information costs and asymmetries-for example, health risks on the job and

${ }^{84}$ See, e.g., FreEman \& Medoff, supra note 65, at 7-11; Hirsch \& Addison, supra note 42, at 188-192; Kuhn, supra note 66, at 229; Donald O. Parsons, The Employment Relationship: Job Attachment, Work Effort, and the Nature of Contracts, in 2 HANDBOOK OF LABOR ECONOMICs 789, 799-810 (Orley Ashenfelter \& Richard Layard eds., 1986).

85 See Hirsch \& Addison, supra note 42, at 188-89; Matthew S. Goldberg, Discrimination, Nepotism, and Long-Run Wage Differentials, 97 Q.J. Econ. 307, 308-14 (1982) (elaborating on monitoring and the theory of discrimination); Peter Kuhn, Malfeasance in Long Term Employment Contracts: A New General Model with an Application to Unionism 28-29 (Nat'l Bureau of Econ. Research, Working Paper No. 1045, 1982), available at http://www .nber.org/papers/w1045.pdf?new_window $=1$.

86 The notion that production workers can contribute knowledge and information to the firm's production processes is the basis of the concept of "quality circles" so popular in Japanese and American management. See generally John L. W. BeCKFORD, Quality: A Critical Introduction (3rd ed. 2010); KaOru Ishikawa, What is Total Quality Control? The Japanese Way 5, 138-40 (David J. Lu trans., 1985); W. Edwards Deming, Out of THE CRISIS 47 (MIT Press ed. 2000).

87 Dau-Schmidt, supra note 38, at 433.

88 See, e.g., id. at 432-33; FreEmAn \& MedofF, supra note 65, at 46-47; see also Richard B. Freeman \& James L. Medoff, The Two Faces of Unionism, 57 NAT'L AfF. 69, 71 (1979).

${ }^{89}$ Freeman \& Medoff, supra note 88 , at 70-71. 
the expected value of health and pension benefits. Individually, it is very costly for employees to collect all of the information necessary to negotiate efficient terms with respect to these conditions of employment. ${ }^{90}$ Unions help solve this problem by hiring experts and taking advantage of economies of scale in collecting and maintaining the necessary information. ${ }^{91}$

Third, unions help promote the efficient enforcement of express or implicit contracts. It is often efficient for the employer and employees to make agreements that are enforceable over considerable periods of time-for example, health and pension benefits. Moreover, in both the private and the public sectors, it is common for employers to pay employees less than their marginal product early in their careers and more than their marginal product later in their careers. ${ }^{92}$ This deferred compensation serves the important purposes of compensating employees for investments in human capital and minimizing employer monitoring costs. ${ }^{93}$ Regrettably, such deferred compensation creates incentives for employers to act opportunistically and fire employees before they receive their deferred wages, while agreements to defer a portion of compensation often remain implicit because of the costs of negotiation and enforcement. ${ }^{94}$ However, they can also be enforced by express terms that act as a check on the arbitrary discharge of employees later in their careers-for example, seniority agreements and just cause clauses. Unions enable the enforcement of such long-term implicit contracts by protecting employees from employers' opportunistic behavior with collective action, seniority rules, just-cause provisions, and arbitration provisions. ${ }^{95}$

Finally, some argue that unions raise productivity by promoting the adjustment of working conditions through the efficient expression of a collective voice rather than costly exit. ${ }^{96}$ In competitive labor markets, a worker's primary mechanism for expressing dissatisfaction with working conditions is to take another job or "exit" the firm. ${ }^{97}$ Individual bargaining over conditions of

90 For information regarding unions and their ability to effectively communicate workplace protections, see Lawrence Mishel \& Matthew Walters, Econ. Pol'y Inst., How Unions Help All Workers 11 (2003), available at www.epi.org/files/page/-/old/briefing papers/143/bp143.pdf.

91 David Madland et al., Ctr. for Am. Progress Action Fund, Unions Make the Middle Class: Without Unions, the Middle Class Withers 16 (2011), available at http://www.americanprogressaction.org/wp-content/uploads/issues/2011/04/pdf/unionsmake themiddleclass.pdf.

92 There is extensive economic literature on implicit labor market contracts. Recent surveys can be found in Parsons, supra note 84, at 799-802; Sherwin Rosen, Implicit Contracts: A Survey, 23 J. Econ. Literature 1144 (1985). See also Dau-Schmidt, supra note 38, at 431-32.

93 Deferred compensation helps minimize monitoring costs because employees who have a portion of their compensation deferred to later years will be less likely to goof-off, fearing loss of the later compensation. See Dau-Schmidt, supra note 38, at 432 n.46.

94 Id. at 432.

95 Id. See also James M. Malcomson, Trade Unions and Economic Efficiency, 93 Econ. J. 51, 52-53 (1983); M.W. Reder, Unionism, Wages, and Contract Enforcement, in ResEARCH in Labor Economics: New Approaches to Labor Unions 27, 46-47 (Joseph D. Reid, Jr. ed., Supp. II 1983); Kuhn, supra note 85.

96 Freeman \& Medoff, supra note 65, at 7-9, 14-15; Freeman \& Medoff, supra note 88, at 70-74, 76-77.

97 Dau-Schmidt, supra note 38, at 433; Freeman \& Medoff, supra note 65, at 7. 
employment is difficult due to the free-rider effect previously discussed and because workers do not want to be identified by their employer as "troublemakers." 98 However, exit is an inefficient mechanism by which to encourage changes in working conditions because it does not communicate what was wrong with the job and also imposes search and retraining costs on both the employee and the employer. Unions help solve this problem by giving workers a collective voice through which they can express dissatisfaction with working conditions without the problems of free riding or employer retaliation. Besides being a more effective method of expressing dissatisfaction with working conditions, the collective voice also saves money by reducing the number of workers who leave jobs and, thus, the amount of search and retraining costs. ${ }^{99}$

\section{Unions as an Important Part of a Pluralist Democracy}

Last but not least, many have argued that free labor unions are an important part of democratic pluralism. Not only do free people, including public sector employees, have the right to organize to petition the government, in a society where the interests of capital are so well organized and financed, it is imperative that workers organize to represent their interests in the legislature. The services provided by public employees are in direct competition for public dollars with alternative state purchases or tax breaks, advocated by special interests or the public at-large. ${ }^{100}$ These competing interests are well organized and funded in their lobbying efforts, including advocates for lower taxes and smaller government in general. ${ }^{101}$ Attempts to silence public employees or hinder their collective public representation ${ }^{102}$ will bias future debate over the merits of the services public employees provide.

The fact that public employees have particular interests as employees of the state should not disqualify them from seeking collective redress from the government, unless we are also willing to disqualify the other lobbyists with direct interests - almost every single lobbyist of consequence in Washington and our state capitals. Indeed, it is probably important that public employees address their particular interests before the government because they have direct experience with the benefits their services provide to society and special expertise and experience on how those services can best be provided and efficiently administered. The fact that these employees also have a personal interest in higher wages and benefits is completely transparent, and the

98 Freeman \& Medoff, supra note 65, at 9.

99 Id. at 8-9, 14-15.

100 See Patrick Michels, Texas Tax Give-Back to Oil Companies Set to Further Drain School Budget, Colo. IndeP. (Sept. 27, 2011), http://coloradoindependent.com/100681 /texas-tax-give-back-to-oil-companies-set-to-further-drain-school-budget.

101 See SHERK, supra note 41, at 1-2.

102 See, e.g., Ala. Educ. Ass'n v. State Superintendent of Educ., 665 F.3d 1234, 1236, 1239 (11th Cir. 2011); Robert Kahn, State's Teachers Call New Law Unconstitutional Political Attack, Courthouse News Service (Feb. 28, 2011), http://www.courthousenews.com /2011/02/28/34492.htm; Susan Martin, State Initiatives Affecting Public Employees' Collective Bargaining Rights, A.B.A. SeC. OF LaB. \& EmP'T Law, June 2011, http://www.ameri canbar.org/newsletter/groups/labor_law/ll_flash/1106_aball_flash/1106_aball_flash_state_in itiatives.html. 
compensation they receive is a matter of public record and easily accounted for in the public debate. ${ }^{103}$

Finally, public employees also share interests with private sector employees in the general organization of the employment relationship and society, and these interests require representation before the government. To disadvantage public employees in the political debate is to further disadvantage worker interests relative to the interests of management and capital in the formulation of our laws and government policies. Even outside of the legislative process, it is important to have employee organization for the efficient evolution of legal rules and social norms. Organized groups have "repeat player" advantages and can better litigate and lobby to establish precedents and social norms. ${ }^{104}$ Employers are certainly organized to represent their interests in the legislature and courts, including the court of public opinion. Unless employee interests are similarly organized in unions, laws, precedents, and social norms will evolve in favor of employer interests and against employee interests. ${ }^{105}$

\section{The Positive View of Public Sector Unions and Collective Bargaining}

Based on the analysis of unions as a collective voice, progressives argue that public employee unions are important in ensuring adequate compensation for public employees, an adequate level of funding for government services, the efficient provision and administration of government services, and a voice for employee concerns in the legislative process. ${ }^{106}$ Thus, they would predict that, although organization would increase public employee wages and benefits, compensation would be commensurate to the compensation enjoyed by comparable private sector employees, although a larger portion might be received in the form of benefits to take advantage of the government's advantages as an insurer. They would also predict that states with public employee organization would have better-funded and administered systems for the provision of government services. Finally, they would argue that the legislative activities of public employee unions help balance the lobbying activities of other groups, offering a more balanced perspective on the costs and benefits of government programs and providing particular expertise, all of which would tend to improve the outcomes of the legislative process.

Even in an ad hoc analysis, there would seem to be some force behind these arguments. First, the government would seem to enjoy monopsony power over a broad array of public employees. Empirical work supports the notion that the government enjoys monopsony power over schoolteachers and pricing

103 For example, in California, under the California Public Records Act, CAL. Gov't Code $\S \S 6250-6270,6275-6276.48$ (2012), all public employee salaries and wages are public record. You can even search them on-line. Max Hennum, Search for State Worker Salaries, SACRAMENTo BeE, http://www.sacbee.com/statepay/ (last updated Jan. 27, 2014).

104 Marc Galanter, Why the "Haves" Come Out Ahead: Speculations on the Limits of Legal Change, 9 Law \& Soc'y Rev. 95, 97-103 (1974); see also Paul H. Rubin, Why is the Common Law Efficient?, 6 J. Legal Stud. 51, 53 (1977).

105 Kenneth G. Dau-Schmidt, An Alternative Economic Analysis of the Regulation of Unions and Collective Bargaining, in Law And Economics: Alternative Economic Approaches to Legal and Regulatory Issues 201, 203, 219 (Margaret Oppenheimer \& Nicholas Mercuro eds., 2005).

106 See supra note 6. 
power with respect to other professionals it commonly employs. ${ }^{107}$ If this is the case, the cost-minimizing strategy for the state in providing public services would be to choke back employment and wages. Even where the government does not enjoy monopsony power in a labor market, it may acquire the ability to act opportunistically with respect to its employees. Any public employee who invests a significant portion of his or her career in acquiring human capital specific to the workings of that state would seem vulnerable to later opportunistic behavior by the employer. No other employer will reward the public employee for that investment. In light of this economic power over its employees, the political nature of the state takes on a different light. State government can be used as a means for taxpayers or consumers and special interests to take advantage of public employees for short-term gain by reneging on promises that have to be enforced over time. It is essential for the efficient enforcement of long-term agreements with the state that such agreements cannot be undone with every change in political power.

\section{Empirical Evidence on Public Sector Unions and Collective Bargaining}

\section{A. Wages and Benefits}

There have been a number of recent empirical studies comparing wages and benefits in the private and public sector. These studies take two different strategies to account for the differences between private and public employees in education and other demographic factors. One strategy is to compare "similar people" by comparing employees with similar educational levels and other demographic factors through comparing means for select populations or through regression analysis. ${ }^{108}$ Alternatively, an analyst might compare "similar positions" by comparing what people get paid in the private and public sector for doing the same job. ${ }^{109}$ The first strategy is far more common because there are many occupations that are not well-represented in both the private and public sectors, and regression analysis allows a fairly sophisticated accounting of compensation differences between private and public employees. ${ }^{110}$ Fortunately, the two methods yield similar results. ${ }^{111}$

Historically, the concern among economists and policy analysts has been whether public pay was too low rather than too high. In evaluating the early empirical evidence, Richard Kearney concluded that " $[\mathrm{u}]$ ntil the rise of [public sector] unions . . . in the 1960s and 1970s, public employees were consistently underpaid relative to similar workers in the private sector."112 With the advent of significant public employee representation in the 1970s, economists became very interested in the comparability of private and public wages and benefits,

\footnotetext{
107 See generally Alan Manning, Monopsony in Motion: Imperfect Competition in LABOR MARKETS (2003).

108 Bender \& Heywood, supra note 16, at 4-5.

$109 I d$. at 5.

110 Dale Belman \& John S. Heywood, Public-Sector Wage Comparability: The Role of Earnings Dispersion, 32 Pub. Fin. Rev. 567, 572-73 (2004).

111 Bender \& Heywood, supra note 16, at 6.

112 Richard Kearney, Labor Relations in the Public Sector 158 (4th ed. 2009).
} 
and began trying to compare the wages and benefits of workers in similar public and private sector jobs. The results of studies using this methodology varied, depending on the sample used and the examined worker characteristics. ${ }^{113}$ Dale Belman and John Heywood examined variation between private and public employees across seven states using Current Population Survey data and found that local government employees earned less than comparable private sector workers in six of the states, and state employees earned less than comparable private sector workers in three of the states. ${ }^{114}$ George Borjas analyzed private and public sector earnings from the 1960s to 2000 and found that public sector employees suffered lower pay than comparable private sector employees; in 2000, men earned about six percent less in the public sector, while women earned about the same in the public sector as the private sector when adjusted for demographic characteristics. ${ }^{115}$ In a particularly detailed analysis of different worker characteristics, Sang-Hyop Lee used National Longitudinal Survey data to find that female state employees earned four percent less than comparable private employees and male state employees earned nine percent less than comparable private employees. ${ }^{116}$ Greg Lewis and Chester Galloway used detailed census data to examine pay differentials in all fifty states and found that both state and local employees were paid less than private employees in forty-four states. ${ }^{117}$ They tentatively concluded that "most [state and local governments] pay less than private firms in the same state for similar workers."118 Finally, in perhaps the most complete study comparing pay between occupations in the private and public sectors, Michael Miller found that private industry paid better for virtually all professional and administrative jobs, but for technical- and clerical-level employees and blue-collar workers the findings were mixed. ${ }^{119}$ Miller's results suggest that at higher skill levels private

113 Keith A. Bender, The Central Government-Private Sector Wage Differential, 12 J. ECON. Survs. 177, 177-78, 181-82 (1998).

114 Dale Belman \& John S. Heywood, State and Local Government Wage Differentials: An Intrastate Analysis, 16 J. LAB. Res. 187, 188-89, 196 tbl.6 (1995).

115 George J. Borjas, Wage Structures and the Sorting of Workers into the Public Sector, in For the People: Can We Fix Public Service? 29, 33 fig.3-2, 34 (John D. Donahue \& Joseph S. Nye Jr. eds., 2003).

116 Sang-Hyop Lee, A Reexamination of Public-Sector Wage Differentials in the United States: Evidence from the NLSY with Geocode, 43 Indus. ReL. 448, 451, 456 (2004). Female local government employees also earned four percent less, while male local government employees earned essentially the same as private sector workers. Id. at 456.

117 Gregory B. Lewis \& Chester S. Galloway, A National Analysis of Public/Private Wage Differentials at the State and Local Levels by Race and Gender 2, 33-34 tbl.5 (Ga. State Univ., Andrew Young Sch. of Policy Studies Research Paper Series No. 11-10, 2011), available at http://papers.ssrn.com/sol3/papers.cfm?abstract-id=1768190. Although Lewis and Galloway report differentials that range from $-15.2 \%$ (Kansas) to $+13.0 \%$ (Nevada) and most state differentials were negative, suggesting that public employees are paid less, most of the reported differentials were within a few percentage points of zero suggesting public and private comparability. $I d$. at 33-34 tbl.5.

118 Id. at 24.

119 Michael A. Miller, The Public-Private Pay Debate: What do the Data Show?, 119 Monthly Lab. Rev. 18, 18 (1996). 
employees enjoy higher pay, but that at lower skill levels public employees enjoy higher pay. ${ }^{120}$

Perhaps the best of the most recent studies on the subject was conducted by Jeffrey Keefe. ${ }^{121}$ Keefe used Current Population Survey data (wages) and Employer Costs of Employee Compensation data (benefits) for the year 2009 to compare private and public employee compensation across educational levels and size of firm, while controlling for a variety of worker characteristics including hours worked, education, experience, organizational size, gender, race, and disability. ${ }^{122}$ He found that public employees are paid wages that are $11.47 \%$ less than those paid comparable private sector employees. ${ }^{123}$ Public employees do indeed enjoy benefits that are a larger share of total compensation $(34.1 \%)$ than the average private sector employer, but only marginally larger than private employees with 500 employees or more $(33.1 \%) .{ }^{124}$ After accounting for public employees' better benefits, Keefe found that they still were paid total compensation packages worth, on average, $3.74 \%$ less than the compensation packages of comparable private sector employees. ${ }^{125}$ Keefe found that the difference between private and public sector compensation varied according to the employee's level of education. Public employees with just a high school education or "some college" earned more than their private sector counterparts, while public employees with a bachelor's degree or an advanced degree earned considerably less. ${ }^{126}$

Keith Bender and John Heywood have recently confirmed Keefe's general findings on a national basis by examining data from several individual states over a period encompassing almost the last three decades. ${ }^{127}$ Using Current

120 Of particular relevance to the legal profession, one of the authors has performed regression analyses controlling for hours of work, years of work experience, grade point average, and many other variables, and found that fifteen years after graduation, government lawyers are paid slightly over $\$ 127.000$ a year less (2004 dollars) than comparable attorneys in large private firms. Kenneth G. Dau-Schmidt, et al., "The Pride of Indiana": An Empirical Study of the Law School Experience and Careers of Indiana University School of Law - Bloomington Alumni, 81 InD. L.J. 1427, 1471 (2006); see also Kenneth G. Dau-Schmidt \& Kaushik Mukhopadhaya, The Fruits of Our Labors: An Empirical Study of the Distribution of Income and Job Satisfaction Across the Legal Profession, 49 J. Legal Edu. 342, at 355 (1999) (government attorneys paid over $\$ 98,000$ per year less than comparable large private firm attorneys in 1992 dollars).

121 See generally KeEFe, supra note 19; Keefe, supra note 10.

122 KeEFE, supra note 19, passim.

123 Id. at 10.

${ }^{124}$ Id. at 7 tbl.3, 8. Keefe found that benefits constituted $26.3 \%$ of total compensation for private employers with less than 100 employees, $29.8 \%$ of total compensation for private employers with 100 to 499 employees, $33.1 \%$ for private employers with 500 or more employees, and $34.1 \%$ for public employers. $I d$.

${ }_{125}$ Id. at 10 tbl.6; see also SCHMIT, supra note 15, at 6 (using CPS data to find that public employees are paid on average four percent less than comparable private sector employees). 126 KeEfe, supra note 19, at 6 tbl.2. Keefe found that the public private pay differential for employees with a high school degree was $6 \%$, some college $9 \%$, an associate's degree $5 \%$, a bachelor's degree $-25 \%$, a professional degree $-37 \%$, a master's degree $-31 \%$ and a doctorate $-21 \%$. Id. In a departure from this pattern, Keefe found that public employees without a high school degree were paid $6 \%$ less than their private sector counterparts. Id. See also Sснмітт, supra note 15, at 6-9 (finding a similar wage leveling in the public sector at the expense of the more highly educated public employees).

127 Bender \& Heywood, supra note 16, at 3. 
Population Survey data from the years 1983 to 2008, Bender and Heywood found that the public/private wage differential for state employees nationally was about $-6 \%$ in 1983 , then close to a little more than $-1 \%$ in the early $1990 \mathrm{~s}$, but has since expanded to a little more than $-11 \%$ in the $2000 \mathrm{~s}^{128}$ The public/ private wage differential for local employees showed a similar pattern of first narrowing and then widening; however, local government employees were consistently paid even less than state employees. ${ }^{129}$ Bender and Heywood examined CPS on an individual state basis for the states of California, Texas, New York, Pennsylvania, Illinois, Michigan, and Florida and found similar patterns, although in some states the public/private wage differential was sometimes positive, indicating that the public employees were then paid slightly more than their private sector counterparts. ${ }^{130}$ The states where public employees fared better over the examined period than the national public/private wage differential of $-11.4 \%$ were Pennsylvania $(-4.5 \%)$, Florida $(-4.8 \%)$, New York $(-7.0 \%)$, California (-9.8\%), and Michigan (-10.1\%). In Illinois $(-12.5 \%)$ and Texas $(-16.6 \%)$, they fared worse than the national average. ${ }^{131}$

Keefe has also done studies using Current Population Survey data and Employer Costs for Employee Compensation data to compare public and private wages and benefits in particular states for the year 2009. Using these data sets, Keefe was able to control for differences between public employees and private employees in education, hours worked, experience, organizational size, gender, race, and disability. Keefe found that: New Jersey public employees received 2.25 percent less in wages and $2.43 \%$ more in total compensation than comparable private sector employees, with neither figure being statistically significant, ${ }^{132}$ California public employees received a statistically significant $6.36 \%$ less in wages and a statistically insignificant $2.29 \%$ more in total compensation than comparable private sector employees; ${ }^{133}$ and Wisconsin public employees received $4.8 \%$ less in total compensation than comparable private sector employees in that state. ${ }^{134}$

\footnotetext{
128 Id. at 6, 9 fig. 1.

129 Id.

130 Id. at 10-13 figs.2-8.

131 Id. at 14 tbl.3.

132 Jefrrey H. Keefe, Econ. Policy Inst., Briefing Paper No. 270, Are New Jersey Public EmployeEs Overpaid? 1, 4, 10 tbl.6 (2010), available at http://cdm15353.content dm.oclc.org/cdm/ref/collection/p15353coll3/id/282.

133 Sylvia A. Allegretto \& Jeffrey Keefe, Ctr. on Wage and Emp't Dynamics, The Truth About Public Employees in California: They Are Neither Overpaid Nor OvERCOMPENSATED 11 tbl.5 (2010), available at http://www.irle.berkeley.edu/cwed/wp /2010-03.pdf.

134 Jefrrey H. Keefe, Econ. Pol'y Inst, Briefing Paper No. 290, Are Wisconsin PubLic Employees Over-Compensated? 1, 9 tbl.4 (2011), available at http://www.epi.org /page/-/old/briefingpapers/BriefingPaper290.pdf.
} 
Graph 1: Public Sector Pay Differential 1983-2008

(FROM OLS REGRESSIONS ON CPS DATA) ${ }^{135}$

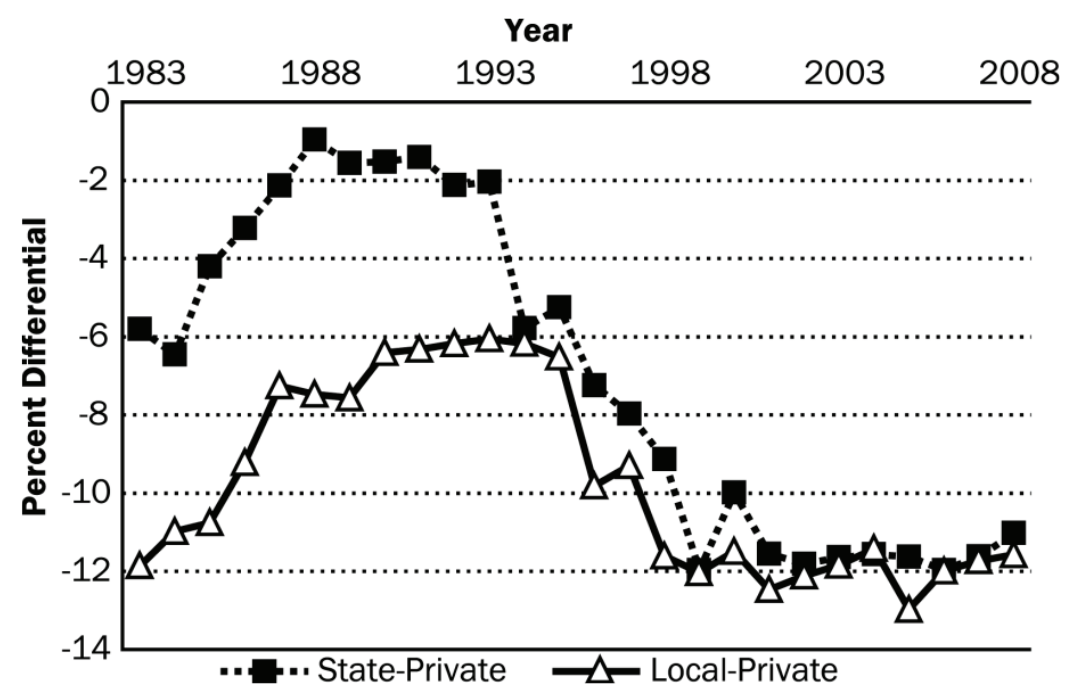

Based on the above analyses, it seems safe to say that although union density in the American economy is much greater in the public sector than in the private sector, ${ }^{136}$ public employee unions have not raised the average total compensation for public employees to a position of parity with the average total compensation of comparable private sector employees. But what has been the impact of public sector unions on their members' wages and benefits in comparison with organized private employees and unorganized private employees? These are in fact quite complex empirical questions made all the more difficult by inadequate data, measurement error, unexplained variance, challenging problems in research design and the "threat effect" that union organization can increase non-union wages. ${ }^{137}$ Although there is not as much recent empirical work on these questions as there is on the public/private pay differential, ${ }^{138}$ the work that does exist seems to suggest that public sector unions raise both their members' wages and benefits by a modest amount, but not by as much as private sector unions raise their members' wages and benefits. ${ }^{139}$ Also like their private sector counterparts, public sector unions tend to have a leveling impact on wages, reducing income disparities between men and women and majority

135 Bender \& Heywood, supra note 16.

136 The percent of employees organized in the public sector is currently around thirty-six percent, while the percent of employees organized in the private sector is currently around eight percent. DAU-Schmidt et al., supra note 21, at 85-86.

137 KeARnEY, supra note 112, at 162-64.

138 The wage and benefit impact of public sector unions is a very complex empirical question, made all the more difficult by inadequate data, measurement error, unexplained variance, challenging problems in research design and the "threat effect" that union organization can increase non-union wages. $I d$.

139 Id. at 161. 
workers and minority workers, and also reducing differences between high and low paid employees. ${ }^{140}$

Studies have been done on the impact of collective bargaining on particular types of public employees, and public employees in general. Much attention has been paid to the impact of collective bargaining on K-12 teachers' salaries and benefits because teachers constitute a large percentage of government employees and are often in the public eye. ${ }^{141}$ The available studies seem to indicate that the mean wage effect of teachers' unions was about five percent in the 1960s and about seven percent from the 1970s through the 1990s. ${ }^{142}$ Despite this wage effect, teachers' salaries barely kept pace with inflation and rose less than other full-time employees during the economic boom years of the 1990s. ${ }^{143}$ Less research exists on police and firefighters, but the work that does exist suggests that organized police enjoy a salary advantage of four percent to eight percent, which peaked around 1977 and has declined since then. ${ }^{144}$ Organized police also enjoy more benefits. ${ }^{145}$ With respect to state employees, early work showed a combined wage and benefits advantage for union workers of around four percent, ${ }^{146}$ while more recent work places the advantage at about seven percent. ${ }^{147}$ After surveying the relevant work, Richard Kearney

140 Id. at $161-62$.

141 Elizabeth McNichol, Ctr. on Budget \& Policy Priorities, Some Basic Facts on State And Local Government Workers 1 (2012), available at http://www.cbpp.org/cms $/$ ffa $=$ view\&id=3410.

142 KeARNEY, supra note 112, at 164-65.

143 Id. at 164. Craig Olson has analyzed data on Wisconsin teachers' salaries and found that they continued to lag behind the private sector over the entire period of 1995-2009. Olson, supra note 17.

144 Kearney, supra note 112, at 165. See also Ronald G. Ehrenberg \& Gerald S. Goldstein, A Model of Public Sector Wage Determination, 2 J. URB. Econ. 223, 233 (1975) (finding that 1967 earnings for unionized municipal employees were greater than those of non-unionized municipal employees by between 2 and 16 percent); Peter Feuille \& John Thomas Delaney, Collective Bargaining, Interest Arbitration, and Police Salaries, 39 Indus. \& LaB. Rel. REv. 228, 229 (1986) (finding that collective bargaining and the availability of interest arbitration tend to have a positive effect on police salaries); W. Clayton Hall \& Bruce Vanderporten, Unionization, Monopsony Power, and Police Salaries, 16 Indus. Rel. 94, 100 (1977) (finding that police salaries are modestly increased by collective negotiations); Richard C. Kearney \& David R. Morgan, The Effect of Employee Organizations on the Compensation of Police Officers, 9 J. Collective Negotiations Pub. Sector 17, 18 (1980). Compare Timothy D. Chandler \& Rafael Gely, Protective Service Unions, Political Activities, and Bargaining Outcomes, 5 J. Pub. Admin. Res. \& Theory 295, 295 (1995) (finding that differences between union and non-union police wages decrease when controlling for union political activity), with Stephen J. Trejo, Public Sector Unions and Municipal Employment, 45 Indus. Lab. ReL. Rev. 166, 166 (1991) (finding that positive correlation between municipal employment and union formation involves economies of scale and is not totally dependent on union's political clout).

145 Kearney, supra note 112, at 165; Peter Feuille et al., Police Bargaining, Arbitration, and Fringe Benefits, 6 J. LAB. Res. 1, 2 (1985); William J. Hunter \& Carol H. Rankin, The Composition of Public Sector Compensation: The Effects of Unionization and Bureaucratic Size, 9 J. Lab. Res. 29, 29-30 (1988).

146 Cf. Richard C. Kearney \& David R. Morgan, Unions and State Employee Compensation, 12 Sт. \& Loc. Gov't Rev. 115, 116 (1980) (noting lower level increases of 1-4 percent in one study, $7.3 \%$ in another study, and the statistics behind such calculations).

147 Dale Belman et al., Public Sector Earnings and the Extent of Unionization, 50 InDus. \& Lab. Rel. Rev. 610, 620 (1997). 
concluded that, although the union advantage in the public sector has varied over time and among occupations and geographic regions, "[t]he best estimate of an overall union effect [in the public sector] is probably 5 to 6 percent."148 This is considerably less than the usual 10 to 15 percent compensation advantage attributed to unions in the private sector. ${ }^{149}$ Given these findings, it seems that, on average, the most that one could reasonably expect of collective bargaining in the public sector is that it would help public employees reach a rough parity in compensation with private sector employees.

\section{B. Productivity}

As previously discussed, ${ }^{150}$ there are divergent views on the impact of unions on the productivity of public employees and the efficiency of the agencies which employ their members. Detractors argue that unions impose high wages, resulting in inefficient production and consumption. ${ }^{151}$ They also argue that unions impose inefficient work rules and interfere with management's flexibility in determining how to undertake production. ${ }^{152}$ Alternatively, supporters of collective bargaining argue that higher wages attract superior workers and decrease turnover costs, increasing productivity. ${ }^{153}$ Moreover, they argue that public sector unions sometimes counter employer monopsony power and can raise efficiency by raising wages and employment closer to efficient levels. ${ }^{154}$ Supporters also argue that unions provide employees with a collective voice so that they can act as an effective monitor of management, make positive contributions to improving productivity, negotiate and enforce efficient contract terms, and further reduce turnover. ${ }^{155}$ These arguments would seem particularly true where the employees are professional employees, well-trained in the conduct of their craft-for example, teachers. Much less empirical work has been done on these questions, but there are some relevant empirical findings to discuss.

The primary argument that unions promote inefficiency is that unions raise wages to inefficient levels, thus causing inefficient production and consumption. Since public sector unions typically achieve only a rough parity with comparable private sector workers in the total compensation their members receive,

\footnotetext{
148 Kearney, supra note 112 , at 166.

149 Id.; see also H. Gregg Lewis, Union Relative Wage Effects: A Survey 153 (1986) (reviewing studies and finding average difference between private and public sector union wage effect of 13\%); David G. Blanchflower \& Alex Bryson, What Effect Do Unions Have on Wages Now and Would Freeman and Medoff Be Surprised?, 25 J. Lab. Res. 383, 391 (2004) (finding that private sector union wage effect decreased between 1983-88 and 1996-2001 from $21.5 \%$ to $17.0 \%$ while public sector union wage effect increased from $13.3 \%$ to $14.5 \%)$.

150 See supra Part III.A-B.

151 See Elise Foley, Mitch Daniels: Public-Sector Unions Shouldn't Exist, Huffington Post, http://www.huffingtonpost.com/2012/06/10/mitch-daniels-unions-public-sector -unions_n_1584396.html (last updated June 10, 2012, 11:05 AM).

${ }_{152} C f . \overline{i d}$. (quoting Indiana Governor Mitch Daniels as saying that with unionization, "government becom[es] its own special interest group").

153 See BorJas, supra note 64, at 451.

154 See id.

155 See Hacker \& Pierson, supra note 69; see also supra Part III.B.
} 
it would seem that there is little, if any, inefficiency caused by public sector union wages. Indeed, Richard Kearney has observed that, at least among teachers, public sector unions have been more concerned with maintaining or increasing employment than increasing wages. ${ }^{156}$ This behavior seems more consistent with the argument posed by proponents of collective bargaining that public sector unions bargain with a monopsonist employer and can increase efficiency by increasing both wages and employment. ${ }^{157}$ Increasing the number of teachers lowers the student-to-teacher ratio, a primary determinant of the effectiveness of our schools. ${ }^{158}$ Detractors might argue that our schools employ too many teachers, and unions make this problem worse, but this argument is increasingly difficult to make and I have yet to see it cogently articulated. Thus, by trying to maintain or increase teacher employment, it would seem that teachers' unions seek to improve school efficiency.

On the question of whether public sector unions impose inefficient work rules, the current debate has been replete with numerous anecdotes but very short on hard empirical evidence. ${ }^{159}$ Detractors of collective bargaining have argued that unions decrease efficiency by: negotiating seniority and just cause provisions which limit the employer's discretion in discharging or laying off employees; resisting merit pay provisions that could encourage employee productivity; and resisting technological or other changes that impact employment. ${ }^{160}$ For example, in the Indiana debate over teacher collective bargaining, Republicans argued that seniority rules in collective agreements were inefficient because they required schools to lay off meritorious younger teachers and retain less meritorious senior teachers. ${ }^{161}$ Furthermore, they argued that merit pay was necessary to encourage increased teacher productivity. ${ }^{162}$ As a result, the legislature adopted, and Governor Mitch Daniels signed, a statute restricting seniority provisions and requiring merit pay. ${ }^{163}$ But these arguments ignore that there are costs as well as benefits to such provisions. Seniority provisions are common in both the public and private sectors, even among unorganized

156 See KeARnEy, supra note 112, at 164-65.

157 See supra note 80 and accompanying text.

158 David Card \& Alan B. Krueger, Labor Market Effects of School Quality: Theory and Evidence, in Does Money Matter?: The Effect of School Resources on Student Achievement and Adult Success 97, 106-07 (Gary Burtless ed., 1996); Alex Molnar et al., Evaluating the SAGE Program: A Pilot Program in Targeted Pupil-Teacher Reduction in Wisconsin, 21 Educ. Evaluation \& Pol'y Analysis 165, 166, 177 (1999).

159 See, e.g., Deanna Martin, Indiana Panel OKs Bill Limiting Teacher Bargaining, BLoomBERG Bus. WK. (Jan. 27, 2011, 9:23 AM), http://www.businessweek.com/ap/financialnews /D9LONVH00.htm.

160 See John T. Addison \& Barry T. Hirsch, Union Effects on Productivity, Profits, and Growth: Has the Long Run Arrived?, 7 J. LAB. ECON. 72, 73, 96-97, 100 (1989) (concluding that a negative effect on productivity from unions has not definitely been proved, but "the contention that unions, on average, significantly raise productivity cannot be sustained"). 161 Cf. Associated Press, Lawmakers Start Work on Teacher Merit Pay Bill, IBJ.com (Feb. 9, 2011), http://www.ibj.com/lawmakers-start-work-on-teacher-merit-pay-bill/PARAMS /article/25208.

162 See id.

163 Dan Carden, Daniels Signs Teacher Merit Pay into Law, NWI Politics (Apr. 30, 2011, 12:15 PM), http://www.nwitimes.com/news/local/govt-and-politics/article_7bd64dab-6955 -5032-b4ed-b0a9a567d2a1.html. See Ind. Code $\$ 20-29-6-4$ (2011) as amended by P.L. 482011, SEC.14; Ind. Code $\S 20-29-6-4.5$ (2011) as added by P.L. 48-2011, SEC 15. 
employers. ${ }^{164}$ This is because seniority provisions allow employers to make credible promises to pay deferred wages that promote efficient monitoring and efficient employee investment in human capital. ${ }^{165}$ Without seniority provisions, future school administrators will be tempted to meet short-run budgeting constraints by reneging on long term implicit contracts and laying off senior workers, not because they aren't good employees, but merely because their wages are higher due to deferred compensation. While such opportunism may meet short term budgeting demands, in the long-run it will discourage good teachers from entering the profession. Although some use of merit pay may be useful, the idea of merit pay was rejected by school boards nationwide in the 1950s, well before teacher organization, because it was subject to racial and gender discrimination and favoritism. ${ }^{166}$ There are costs as well as benefits to administrative discretion and it is not an easy question whether greater administrative control will increase or decrease public sector productivity. In the case of deferred compensation and seniority, or indeed any efficient contract over time, it is important that the terms and conditions of public employment be insulated from immediate response to changing political winds. Whether restrictions on administrative discretion decrease or increase public employee productivity and the efficiency of their agencies is an empirical question.

Despite the difficulty of measuring productivity in service industries, ${ }^{167}$ several scholars have tried to measure the impact of unions on productivity in the public sector. One of the few straightforward measures of productivity in services is the mortality rate of heart attack patients in hospitals. In a 2004 study, Michael Ash and Jean Seago found that unionization in public hospitals led to significantly lower mortality rates. ${ }^{168}$ Consistent with this, in an earlier study Charles Register found that unionization leads to increased productivity in public hospitals based on more mundane measures of patient care. ${ }^{169}$

The effect of unionization on teacher productivity has been fairly extensively studied, primarily using student test scores as the indicator of productivity. The results have been mixed. In one of the earliest studies, Randall Eberts and Joe Stone found that, after correcting for various factors, unionized public schools enjoyed student test scores that were three percent higher overall, and seven percent higher for average students. ${ }^{170}$ These union-positive results were

164 Daniel B. Cornfield, Seniority, Human Capital, and Layoffs: A Case Study, 21 Indus. Rel. 352, 352 (1982); Katharine G. Abraham \& James L. Medoff, Length of Service and Layoffs in Union and Nonunion Work Groups, 38 Indus. \& LAB. Rel. Rev. 87, 87 (1984); Sangheon Lee, Seniority as an Employment Norm: The Case of Layoffs and Promotion in the US Employment Relationship, 2 Socio-Econ. Rev. 65, 66 (2004).

165 See supra note 95 and accompanying text.

166 See Randall Eberts et al., Teacher Performance Incentives and Student Outcomes, 37 J. Hum. Resources 913, 913 (2002).

167 See KeARnEy, supra note 112, at 208; Lori Taylor, Economic Approaches to School Efficiency, in Economics of Education 210 (Dominic J. Brewer \& Patrick J. McEwan eds., 2010).

168 Michael Ash \& Jean Ann Seago, The Effect of Registered Nurses' Unions on HeartAttack Mortality, 57 Indus. \& Lab. Rel. Rev. 422, 422 (2004).

169 Charles A. Register, Wages, Productivity, and Costs in Union and Nonunion Hospitals, 9 J. LAB. REs. 325, 329-30 (1988).

170 Randall W. Eberts \& Joe A. Stone, Teacher Unions and the Productivity of Public Schools, 40 Indus. \& Lab. Rel. Rev. 354, 362 (1987). 
first hotly contested by Michael Kurth, ${ }^{171}$ but then supported by later rework of the same data by Howard Nelson and Jewell Gould. ${ }^{172}$ In her 1996 study, Caroline Hoxby found that teachers' unions increased school budgets and improved the student-teacher ratio, but had no positive impact on student test scores. ${ }^{173}$ Both before and after Hoxby, several studies found positive effects on teacher productivity from unionization, ${ }^{174}$ while others have found negative effects. ${ }^{175}$ If any pattern emerges from this collection of results, it seems to be that the unionization of teachers increases the test scores of average students, but has little effect on the test scores of the highest and lowest performers in schools, and may even hurt the performance of low-performing students. ${ }^{176}$ It is also quite plausible that, as in the private sector, the impact of unionization on productivity in the public sector depends on the attitude of the parties. If management and the union are recalcitrant and fight, productivity goes down; but, if the parties negotiate and work cooperatively, productivity can increase. ${ }^{177}$

\section{CONClusion}

These have been contentious times in the long-running debate over the merits of public sector collective bargaining. After several decades in which the question seemed largely settled in favor of a system of collective consultation with recourse to neutral mediation, fact-finding, or arbitration (but largely without a right to strike) at the state and federal level, the question has now been reopened in the debate over how to respond to the recent decline in private employment prospects and government revenue. Although the detractors of public sector collective bargaining have alleged that this institution has resulted

171 Michael M. Kurth, Teachers' Unions and Excellence in Education: An Analysis of the Decline in SAT Scores, 8 J. LAB. REs. 351, 351 (1987).

172 F. Howard Nelson \& Jewell C. Gould, Comment, Teachers' Unions and Excellence in Education, 9 J. LAB. RES. 379, 379 (1988).

173 See Caroline Minter Hoxby, How Teachers' Unions Affect Education Production, 111 Q.J. Econ. 671, 671, 695, 700-01, 707 (1996).

174 See Morris M. Kleiner \& Daniel L. Petree, Unionism and Licensing of Public School Teachers: Impact on Wages and Educational Output, in When Public Sector Workers Unionize 305, 317 (Richard B. Freeman \& Casey Ichniowski eds., 1988); Howard Nelson \& Michael Rosen, Inst. for Wisconsin's Future, Are Teachers' Unions Hurting American Education? 4 (1996); Laura M. Argys \& Daniel I. Rees, Unionization and School Productivity: A Reexamination, 14 Res. LAB. Econ. 49, 49-68 (1995); F. Charles A. Register \& Paul W. Grimes, Collective Bargaining, Teachers, and Student Achievement, 12 J. Lab. Res. 99, 106-07 (1991); Lala Carr Steelman et al., Do Teacher Unions Hinder Educational Performance? Lessons Learned from State SAT and ACT Scores, 70 HARV. Educ. Rev. 437, 448 (2000); Harris L. Zwerling \& Terry Thomason, The Effects of Teacher Unions on the Probability of Dropping Out of High School, 23 J. Collective NegotiaTions Pub. Sector 239, 239 (1994).

175 Randall W. Eberts, Union Effects on Teacher Productivity, 37 Indus. \& Lab. Rel. Rev. 346, 346 (1984); Mark Meador \& Stephen J. K. Walters, Unions and Productivity: Evidence from Academe, 15 J. LAB. Res. 373, 373 (1994).

176 Kearney, supra note 112, at 209-10; Morley Gunderson, Two Faces of Union Voice in the Public Sector, in What Do Unions Do? A Twenty-Year Perspective, 401, 412 (James T. Bennett \& Bruce E. Kaufman eds., 2007); Katharine Strunk, The Economics of Teachers Unions in the United States, in Economics OF EducAtion, supra note 167, at 288. 177 See Hirsch \& AdDison, supra note 42, at 203-04. 
in public sector wages and benefits far out-pacing private sector compensation, as well as significant inefficiencies in government administration, neither of these claims seems warranted by the existing empirical literature. When taking into account important differences between the public and private sectors, including public employees' comparatively higher education levels, recent empirical work suggests that collective bargaining has allowed public employees to, at best, keep pace with private sector compensation (although, predictably, public sector employees take a larger share of their compensation in benefits). Similarly, although there is much less work on the subject, the existing empirical research makes it clear that unions typically do not have substantial negative effects on public employee productivity, and may even raise productivity in some cases. Moreover, there is evidence that public sector unions can have a beneficial impact on the programs in which their members work in highlighting the benefits of those programs and ensuring more adequate funding. Although the positive view of public sector collective bargaining that previously prevailed in American public policy is not always strictly true, it seems to much more closely track the available empirical work than the older negative view that has since reemerged in American state politics. 